\title{
The Earthquakes are not produced by Occurrence of Fault
}

\author{
by \\ Sei Takagi \\ Meteorological Research Institute, Tokyo
}

(Received February 27, 1974)

\begin{abstract}
Many theories of the earthquake are founded upon the hypothesis that earthquakes are produced by the occurrence of a fault, but the actual phenomena go against this hypothesis. If the hypothesis were correct, the radiation pattern ought to be shown as quadrant type, but many actual patterns are not; they are conical. So the author considers that the earthquakes are not produced by the occurrence of a fault but are produced by magma explosion in a magma pocket. In this paper two earthquakes are shown for examples.
\end{abstract}

\section{Mean of the radiation patterns}

The $\mathrm{P}$ wave of an earthquake indicates the direction of its center's motion. If a part of the earthquake center expands first, the $\mathrm{P}$ wave radiated from the part will be a commpression wave. And if another part of the earthquake center contracts first, the $\mathrm{P}$ wave radiated from the part will be a dilatation wave. The distribution of these $\mathrm{P}$ waves makes a radiation pattern. So the radiation pattern indicates the initial mechanism of the earthquake. Therefore the radiation pattern which is made by the occurrence of a fault must show a quadrant type. If the earthquake is produced on the Plate Tectonics Hypothesis, the Sea Floor Spreading Hypothesis, etc., the radiation patterns must be shown as quadrant type, because these hypotheses need the occurrence of a fault. If the actual radiation pattern is not a quadrant type, the earthquake can not be produced by the occurrence of a fault.

\section{Radiation patterns of actual earthquakes}

The author takes the Niigata Earthquake and the Off Echizen-Misaki Earthquake as examples. The former occurred at about 1 o'clock on the afternoon of June 16, 1964. The violent tremors shook the Niigata City area violently, and within 15 minutes after the shock, a Tsunami whose height was about 5 meters hit the area. Its magnitude was 7.5 , and dead 26 . Its location was $38^{\circ} 21^{\prime} 0$ N., $139^{\circ} 11^{\prime} 0 \mathrm{E}$., and depth was 40 $\mathrm{km}$. The Echizen-Misaki Earthquake occurred at about a half after 6 o'clock on the morning of March 27, 1963. The violent tremor shook Tsuruga City area, but fortunately there were no casualties. Its Magnitude was 6.9. Its location was $35^{\circ} 47^{\prime} .0 \mathrm{~N}$, $135^{\circ} 46^{\prime} .0 \mathrm{E}$., and its depth was $0 \mathrm{~km}$. 


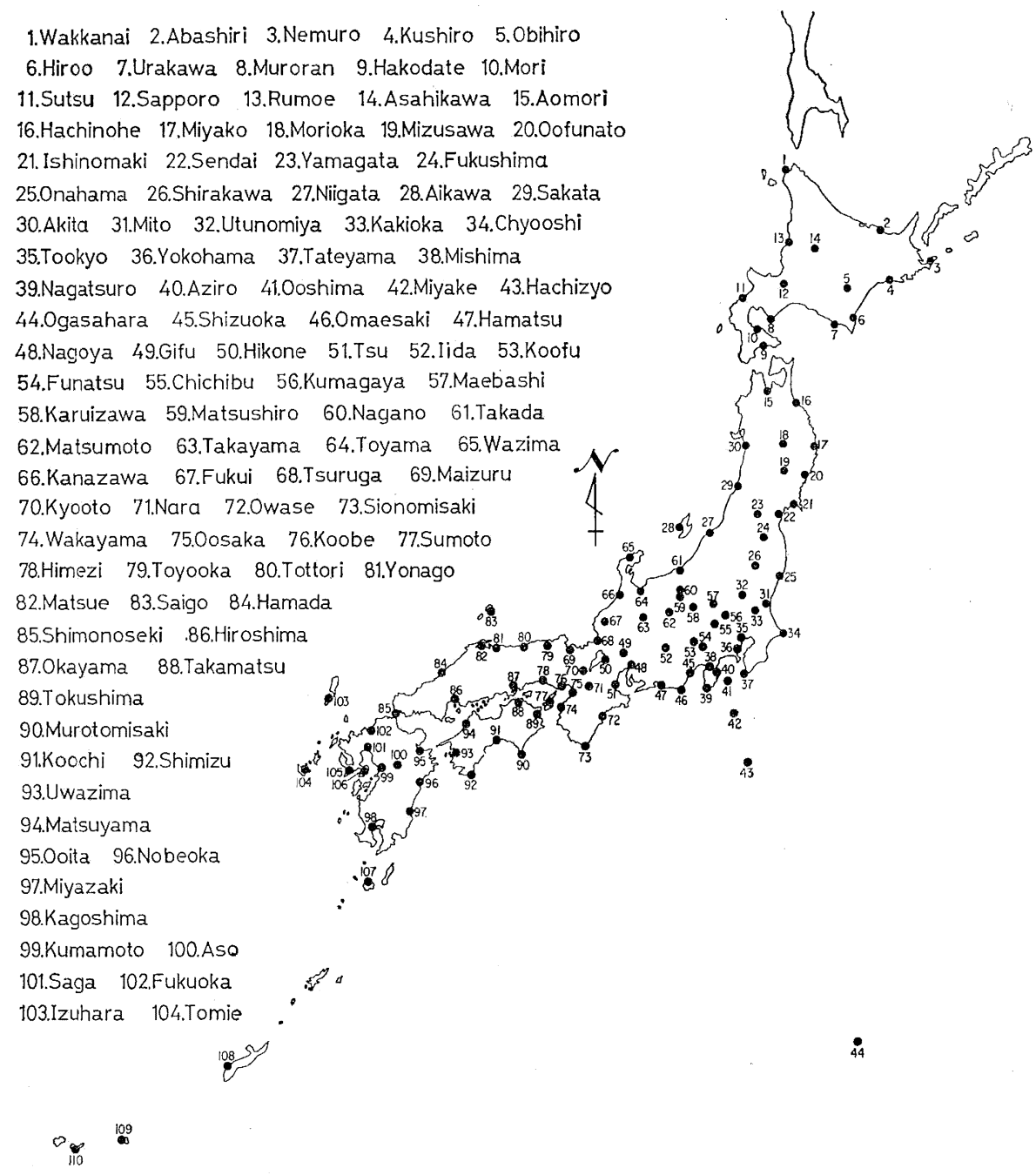

1.Wakkanai 2.Abashiri 3.Nemuro 4.Kushiro 5.Obihiro 6.Hiroo 7.Urakawa 8.Muroran 9.Hakodate 10.Mori 21. Ishinomaki 22.Sendai 23.Yamagata 24.Fukushima 25.Onahama 26.Shirakawa 27.Niigata 28.Aikawa 29.Sakata 30.Akita 31.Mito 32.Utunomiya 33.Kakioka 34.Chyooshi 35.Tookyo 36.Yokohama 37.Tateyama 38.Mishima Aro 4 Miyake 43. 54.Funatsu 55.Chichibu 56.Kumagaya 57.Maebashi 58.Karuizawa 59.Matsushiro 60.Nagano 61.Takada 62.Matsumoto 63.Takayama 64.Toyama 65.Wazima 66.Kanazawa 67.Fukui 68.Tsuruga 69.Maizuru 70.Kyooto 71.Nara 72.0wase 73.Sionomisaki 74. Wakayama 75.0osaka 76.Koobe 77.Sumoto 78.Himezi 79.Toyooka 80.Tottori 81.Yonago 82.Matsue 83.Saigo 84.Hamada 85.Shimonoseki .86.Hiroshima 88.Takamatsu 89.T okushima 91.Koochi 92.Shimizu 93.Uwazima 94.Matsuyama 95.Ooita 96.Nobeoka 97.Miyazaki 98.Kagoshima 99.Kumamoto 100.Aso 101.Saga 102.Fukuoka 103.Izuhara 104.Tomie 


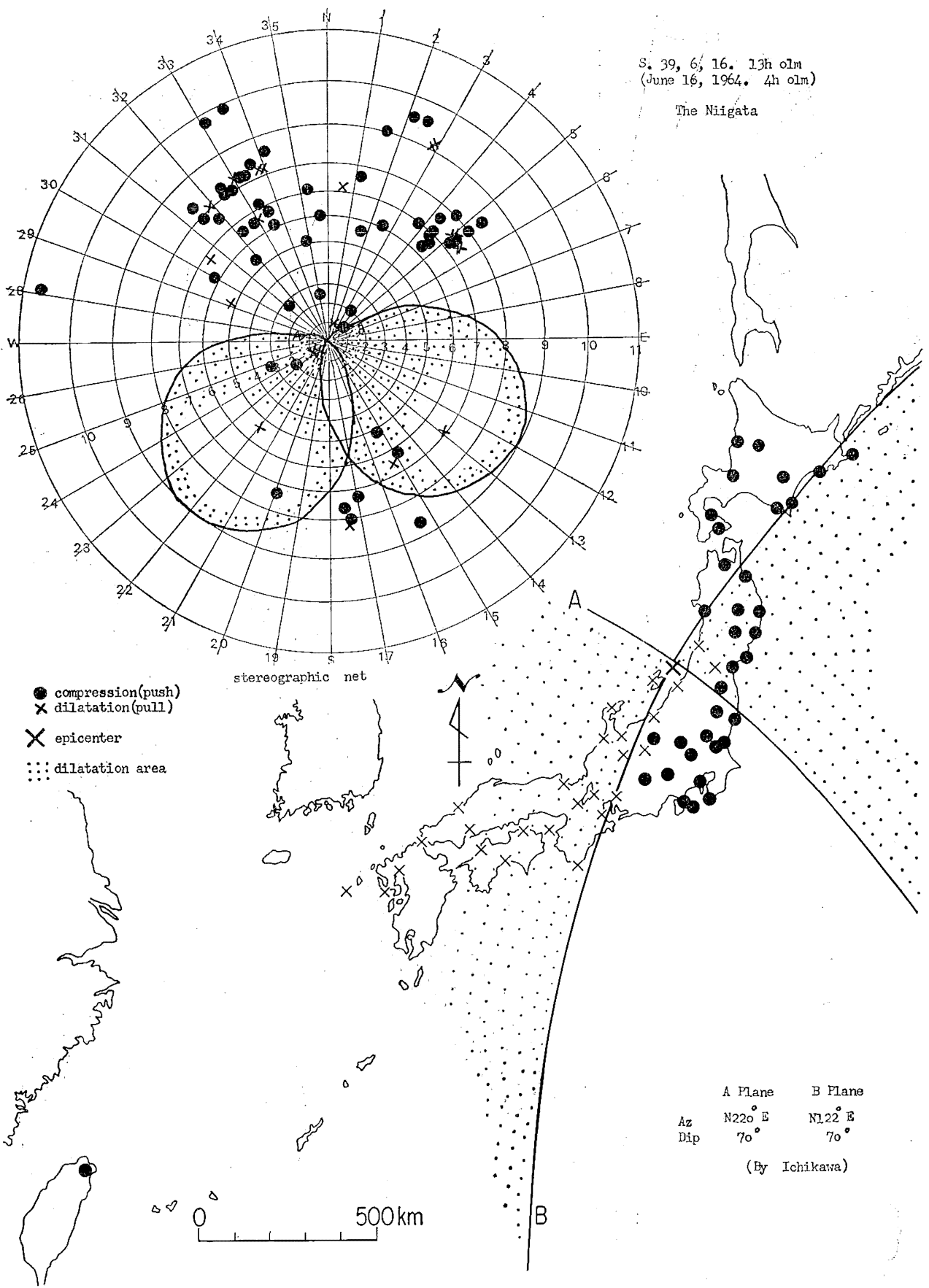

Fig. 2. Radiation pattern for the Niigata Earthquake at about 1 o'clock on the afternoon of June 16, 1964. It is classified by M. Ichikawa as quadrant type, but many observations at Hachinohe (16), Miyako (17), Morioka (18), Oofunato (20), Mizusawa (19), Ishinomaki (21), Sendai (22), Fukushima (24), Nemuro (3), Niigata (27), Matsumoto (62) and Nagoya (48) belie this classification. The upper left figure shows observations the world over plotted on a stereographic net. 


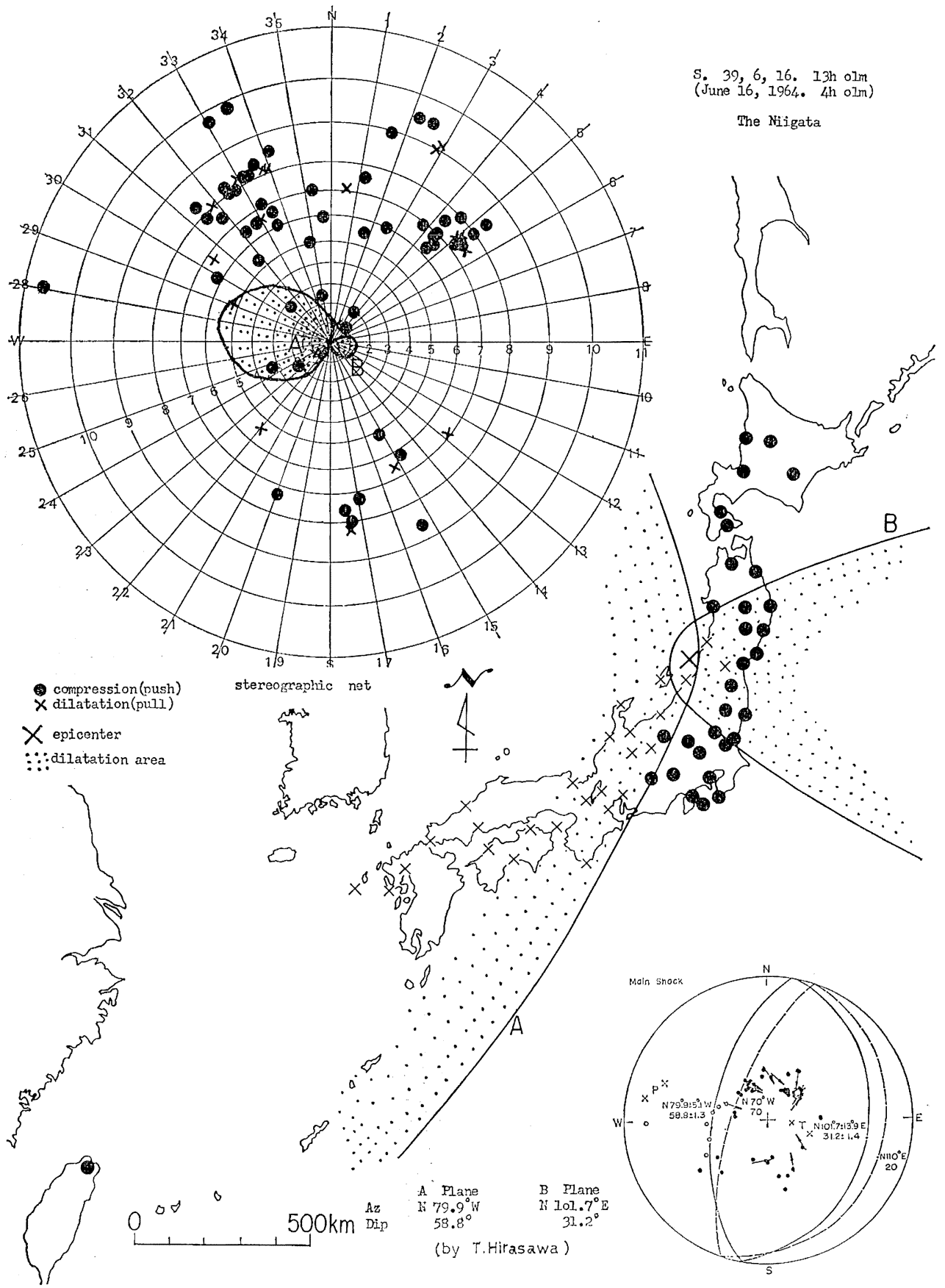

Fig. 3. Radiation pattern for the same earthquake as shown in Fig. 2. It is classified by $\mathrm{T}$. Hirasawa as quadrant type, but many observations at Miyako (17), Oofunato (20), Morioka (18), Mizusawa (19), Ishinomaki (21), Sendai (22), Fukushima (24), Shirakawa (26), Onahama (25), Mito (31) and Niigata (27) are against his quadrant type. The upper left figure shows observations the world over plotted on a stereographic net. 


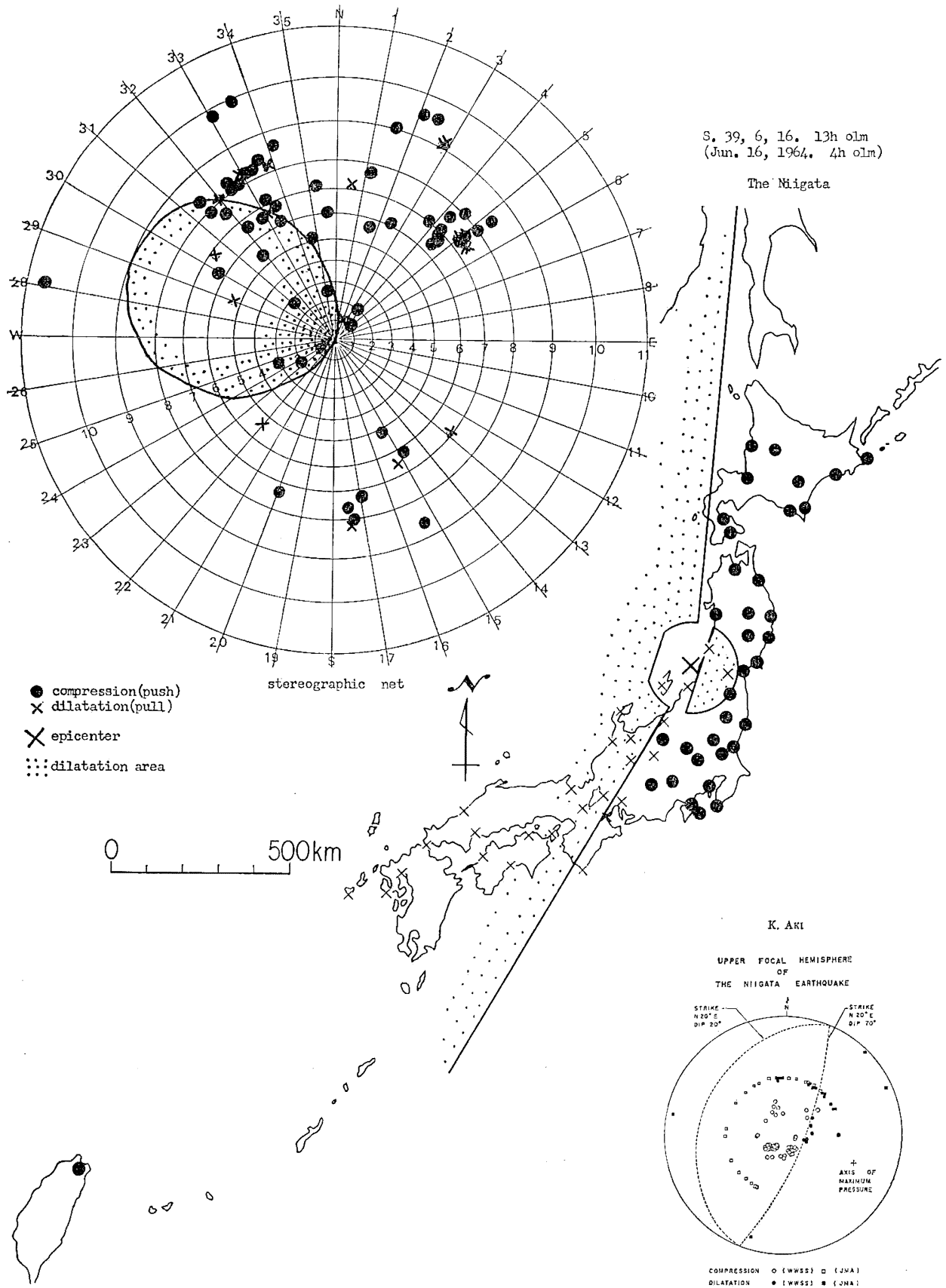

Fig. 4. Radiation pattern for the same earthquake as above two examples. It is classified by $\mathrm{K}$. AKI as quadrant type. He makes this pattern with knowledge of the Mohorovicic Layer, but observations at Niigata (27), Aikawa (28), Takada (61), Matsumoto (62), Nagoya (48) and Shionomisaki (73) still go against the quadrant type. 


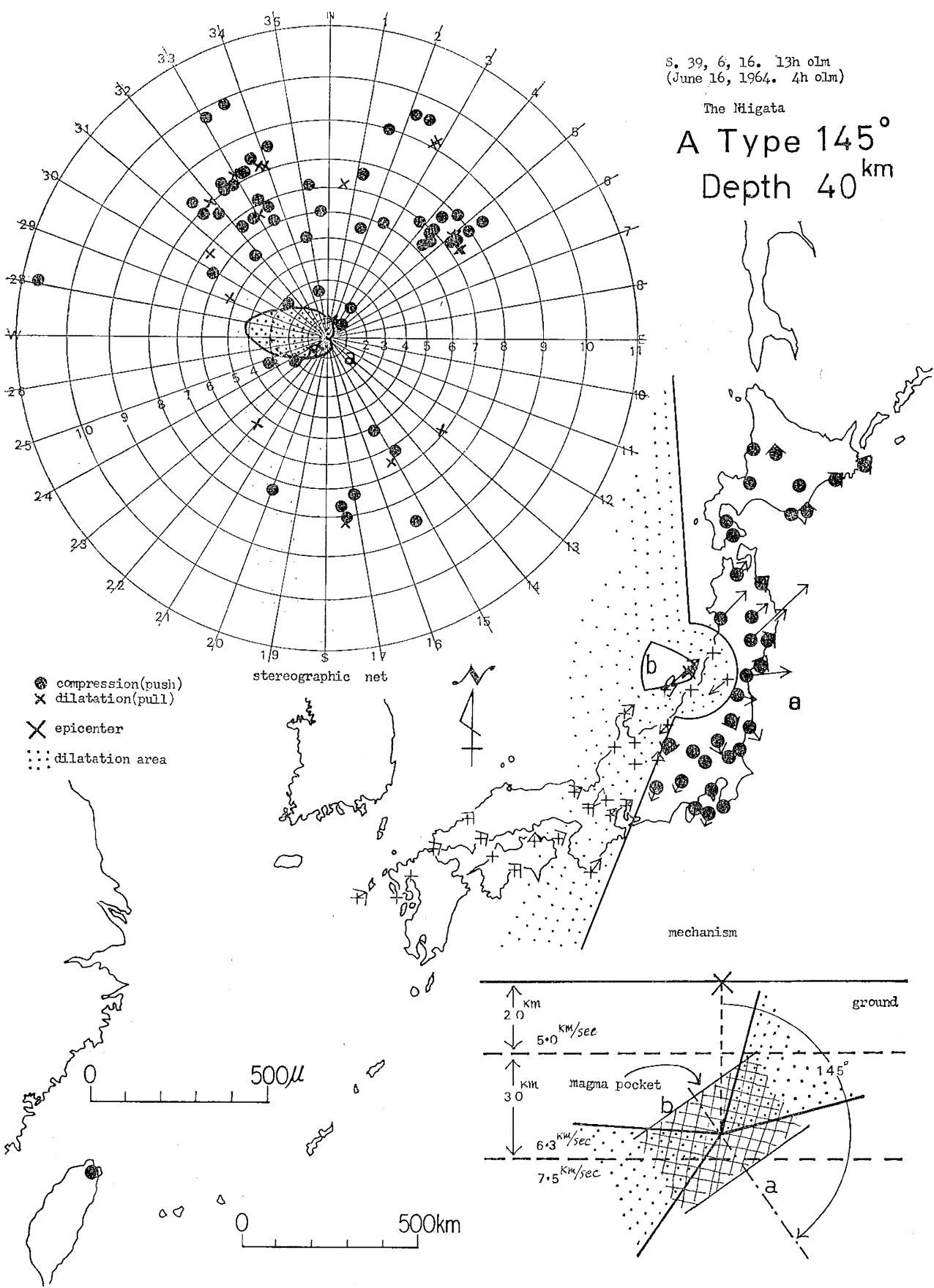

Fig. 5. Radiation pattern for the same earthquake as above three examples. It is classified by the author as conical type, of course with knowledge of the Mohorovicic Layer shown in Fig. 6. This pattern accords with the observations without exception. Therefore the radiation patterns of earthquakes are not quadrant type but conical. 
Az. N122 E. But many observations at Hachinohe (16), Miyako (17), Morioka (18), Oofunato (20), Mizusawa (19), Ishinomaki (21), Sendai (22), Fukushima (24), Nemuro (3), Niigata (27), Matsumoto (62) and Nagoya (48) belie this classification.

The upper left figure in Fig. 2 represents the distribution of the first motions observed over the world plotted on a stereographic net.

Fig. 3 shows the radiation pattern which is classified by T. HiRAsawa (1965) as quadrant type. Elements of its nodal planes are Dip $58.8^{\circ}$, Az. N280.8 $\mathrm{E}$, and Dip $31.2^{\circ}$, Az. N101.7 $7^{\circ}$. But many observations at Miyako (17), Oofunato (20), Morioka (18), Mizusawa (19), Ishinomaki (21), Sendai (22), Fukushima (24), Shirakawa (26), Onahama (25), Mito (31) and Niigata (27) also run counter to the quadrant type.

Fig. 4 shows the radiation pattern which is classified by K. AkI (1966) as quadrant type. He makes this pattern with the knowledge of the Mohorovicic Layer. So this pattern is more excellent than the above two. Elements of its nodal planes are Dip $20^{\circ}$, Az. N110 E, and Dip $70^{\circ}$, Az. N290 E. But observations at Niigata (27), Aikawa (28), Takada (61), Matsumoto (62), Nagoya (48) and Shionomisaki (73) still go against his quadrant type.

Fig. 5 shows the radiation pattern for the same earthquake, which is classified by the author (1965) as conical type, of course with the knowledge of the Mohorovicic Layer shown in Fig. 6. This is a Push Conical Type (A type), the slope of the principal axis is $145^{\circ}, \mathrm{Az} . \mathrm{N} 95^{\circ} \mathrm{E}$. On this type the reader is referred to the author's treatise (1953). This pattern accords with the observations without exception, and far more excellent than the above three that are classified as quadrant type.

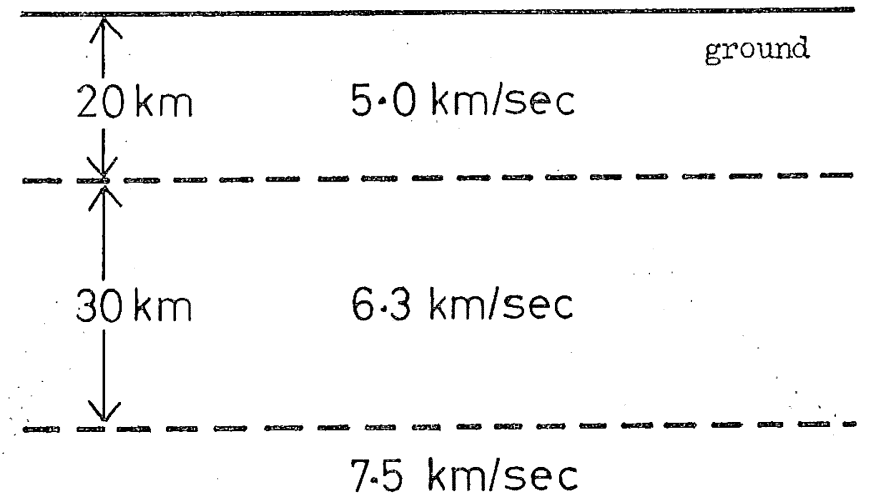

Fig. 6. Underground structure (Mohorovicic Layer).

Therefore the radiation patterns of earthquakes are not quadrant type but conical. The conical pattern indicates that this earthquake was produced by magma explosion in a magma pocket as shown in the lower right figure of Fig. 5.

\subsection{On the Off Echizen-Misaki Earthquake}

The radiation pattern shown in Fig. 7 is classified by M. IchikAwA (1971) as quad- 

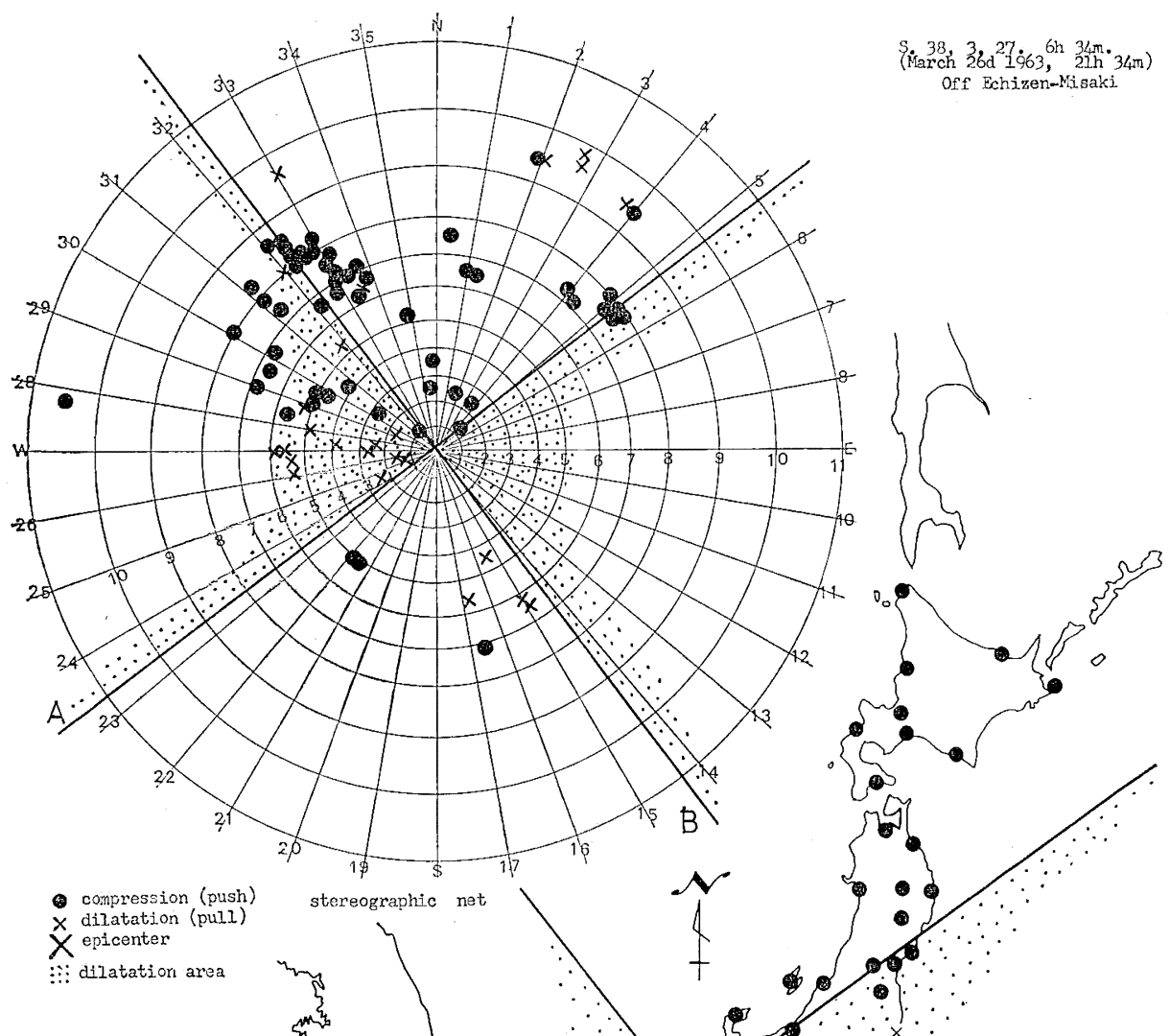

3

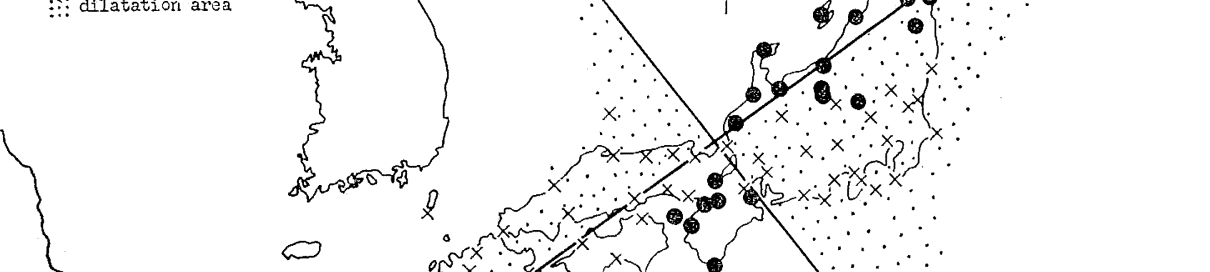

Xn

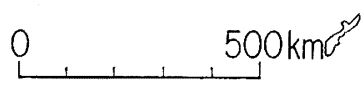

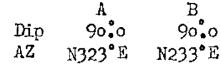

(by Ichikawa)

Fig. 7. Radiation pattern for the Off Echizen-Misaki Earthquake at about a half after 6 o'clock on the morning of March 27, 1963. It is classified by M. IcHikawa as quadrant type, but many observations at Ishinomaki (21), Sendai (22), Fukushima (24), Maebashi (57), Nagano (60), Matsushiro (59), Koobe (76), Himezi (78), Takamatsu (88), Koochi (91) and Amamiooshima (107) do not conform to this type. And the world observations which are shown in the upper left figure do not harmonize with this type. 


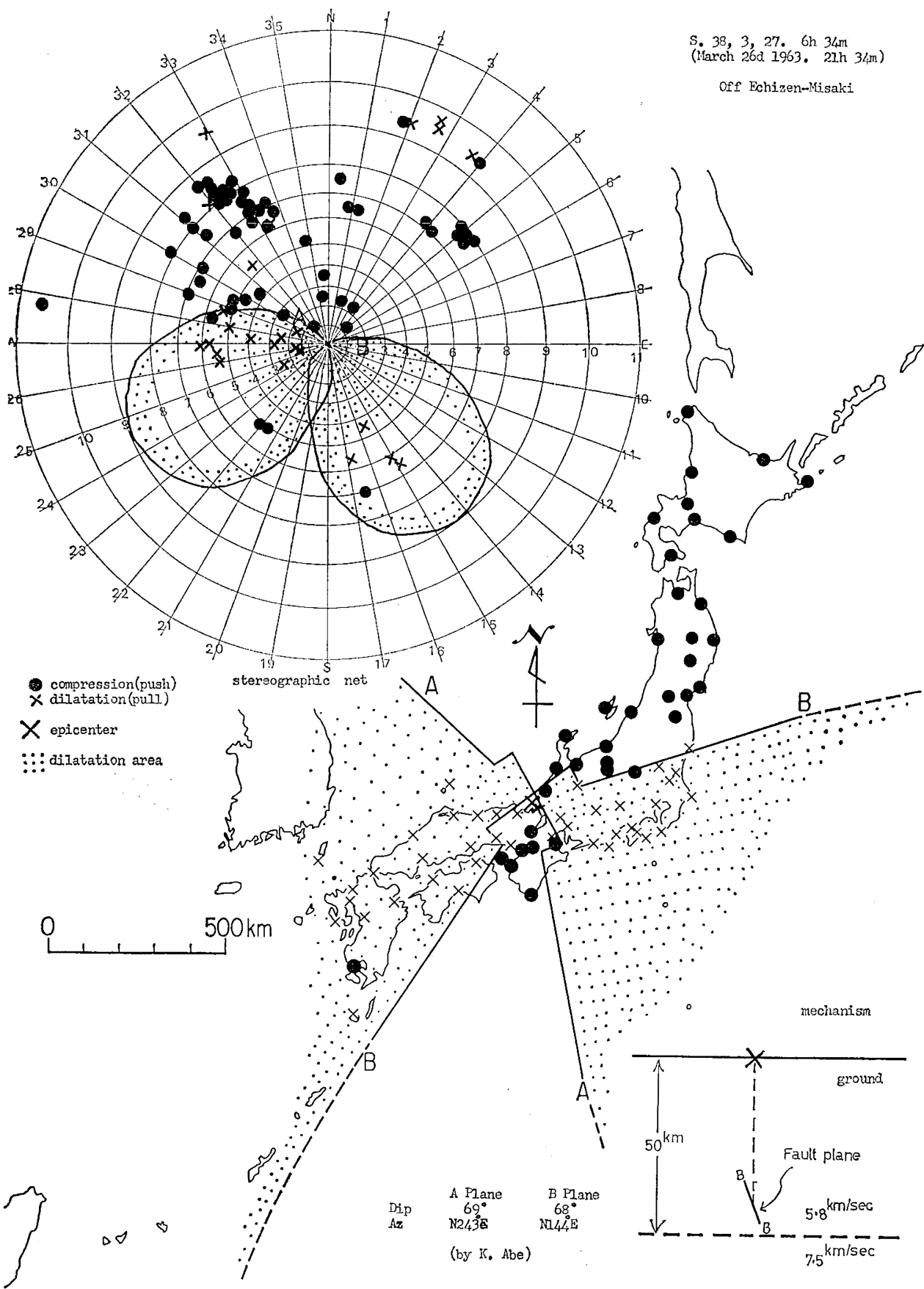

Fig. 8. Radiation pattern for the same earthquake as shown in Fig. 7. It is classified by $\mathrm{K}$. $A_{B E}$ as quadrant type with the knowledge of the Mohorovicic Layer. But observations at Maebashi (57), Fukui (67), Tsuruga (68), Maizuru (69) and Koobe (76) are against this quadrant pattern. Namely, observations which exist in the conversion circle do not harmonize with this type. 


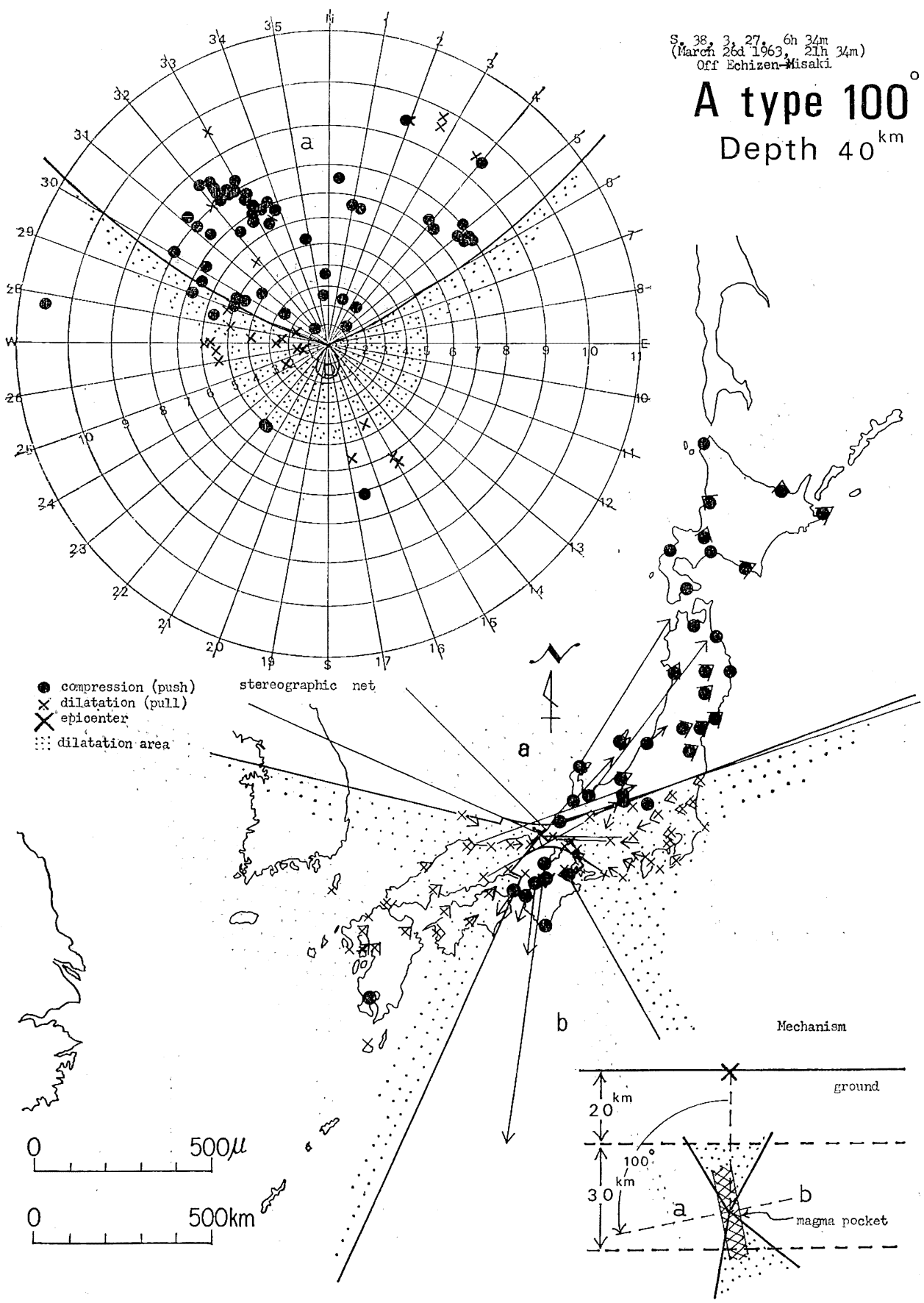

Fig. 9. Radiation pattern for the same earthquake as the above two examples. It is classified by the author as conical type, of course with the knowledge of the Mohorovicic Layer shown in Fig. 6. This pattern accords with the observations without exception. Therefore the radiation patterns for earthquakes are not quadrant type but conical. 
rant type. Its elements of nodal planes are Dip $90^{\circ}, \mathrm{Az} . \mathrm{N} 323^{\circ} \mathrm{E}$, and Dip $90^{\circ}, \mathrm{Az}$. N233 ${ }^{\circ}$ E. But many observations at Ishinomaki (21), Sendai (22), Fukushima (24), Maebashi (57), Nagano (60), Matsushiro (59), Koobe (76), Himezi (78), Takamatsu (88), Koochi (91) and Amamiooshima (107) do not conform to this type. And observations the world over which are shown in the upper left figure do not harmonize with this type. So this pattern is not quadrant.

Fig. 8 shows the radiation pattern which is classified by K. ABE (1973) as quadrant type. Its elements are Dip $69^{\circ}, \mathrm{Az} . \mathrm{N} 234^{\circ} \mathrm{E}$ and Dip $68^{\circ}, \mathrm{Az} . \mathrm{N} 144^{\circ} \mathrm{E}$. He makes this pattern with the knowledge of the Mohorovicic Layer. So this is more excellent than above IcHIKAwA's pattern. But observations at Maebashi (57), Fukui (67), Tsuruga (68), Maizuru (69) and Koobe (76) are against this pattern. Namely, observations which exist in the conversion circle do not harmonize with the quadrant. So this pattern is not quadrant.

Fig. 9 shows the radiation pattern which is classified by the author as conical type, of course with the knowledge of the Mohorovicic Layer shown in Fig. 6. This is Push Conical Type (A type), the slope of its principal axis is $100^{\circ}, \mathrm{Az} . \mathrm{N} 2{ }^{\circ} \mathrm{E}$. This pattern accords with the observations almost without exception, and far more excellent than above two that are classified as quadrant type. Therefore the radiation patterns for the earthquakes are not quadrant type but conical.

The conical pattern for this earthquake indicates that it was produced by magma explosion in a magma pocket as shown in the lower right figure of Fig. 9.

\section{Conclusion}

In spite of many studies classifieing these radiation patterns as quadrant type, these patterns do not harmonize with quadrant but coincide with conical. This appears to be the strongest proof that earthquakes are not produced by the occurrence of a fault but are produced by magma explosion in a magma pocket.

So the Fault Theory for the earthquake (the Continental Drift Hypothesis, the Mantle Convection Hypothesis, the Sea Floor Spreading Hypothesis and the Plate Tectonics Hypothesis) might be unrealistic assumptions.

The author wishes to express his hearty thanks to M. IchIKAwA and K. ABE for their cooperations.

\section{References}

ABE, K., 1973: Fault motion of the Off Echizen-Misaki Eathquake of 1963. Meeting Seism. Soci. Japan, May 1973.

AkI, K., 1966: Generation and propagation of G waves from the Nigata Earthquake of June 16, 1964. Bull. of the Earthquake Res. Inst., 44, 23-72, 73-88.

Hirasawa, T., 1965: Source mechanism of the Niigata Earthquake of June 16, 1964, as derived from body waves. J. Phys. Earth, 13, 35-66.

IcHIKAWA, M., 1971: Reanalyses of mechanism of earthquakes which occurred in and near Japan, and statistical studies on the Nodal Plane solutions obtained, 1926-1968. Geophys. Mag., 35, 207-274. 
TAKAGI, S., 1950: On the distribution of initial motion of seismic waves (Summary). The Memories of the Koobe Marine Observatory, 8, 50-68.

, 1953: On the origin of earthquake (the 10th paper), types of distribution of initial motions of earthquakes in the Mohorovicic layer. Quart. J. Seismology, 18, 49-65.

, 1965: On relation between the geological structure and the radiation pattern of the Niigata Earthquake. Quart. J. Seismology, 29, 27-30.

\section{地震は断 層の生成によって起こっていない}

高木聖*

地震は断層の生成によって起こると仮定して, 多くの学説が組み立てられているが，はたして，地震は断

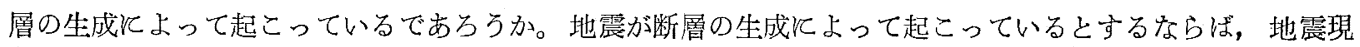
象としては, 初動分布が 4 象限型痤なていなければならない。初動分布は, 震源の最初の動きを表示して いるものであるから，すべての地震学説代対して生殺与奪権を握っている。ところが，筆者が，たびたび報 告しているように，初動分布は 4 象限型でないと考光る方が，現象飞忠実である。本文飞，その，はっきり した例を示している。

昭和 39 年 6 月 16 日 (1964 年) の新潟地震は, 多くの人命や構築物飞被害を与光, 地震予知 Project が始 まった当初であったから, 多くの人々によって調查された。市川政治は, 断層説の立場から, Fig. 2 飞示す ような初動分布であろうと暫定的淍查していた。とれとよると, 一つの節平面は Dip $70^{\circ}$ で Az. N220 ${ }^{\circ} \mathrm{E}$ であり，他の節平面は Dip $70^{\circ} て ゙ ~ A z . ~ N 122^{\circ} \mathrm{E}$ である。この節平面が地表に描く節線は Fig. 2 となる。 しかし, 多くの観测点（八戸，宮古，盛岡，大船渡，水沢，石巻，仙台，福島，根室，新潟，松本，名古屋, 等）が，この 4 象限型区分飞，はまっていない。

同椂飞，平沢朋郎 (1965年) も，断層説の立場から，同じ地震の初動分布を区分している。それとよると， 一つの節平面は Dip $58.8^{\circ}$ で, Az. N280.1ํㅡ であり, 他の節平面は Dip $31.2^{\circ}$ で, Az. N $101.7^{\circ} \mathrm{E}$ となっ ている。これと従って区分したものが, Fig. 3 である。これも多くの観測点（宮古, 大船渡, 盛岡, 水沢, 石巻, 仙台, 福島, 白河, 小名浜, 水戸, 新潟, 等) が, この 4 象限型の区分飞, はまっていない。

安芸敬一(1966年) も, 同㥞飞, 断層説の立場から, この初動分布を区分している。彼は Mohorovicic 層 の存在を認めているので, 前 2 者より，かなりよくなっている。それが Fig. 4 である。それ斿よる，一 つの節平面は Dip $20^{\circ}$ で, Az. $\mathrm{N} 110^{\circ} \mathrm{E}$ であり, 他の一つは Dip $70^{\circ}$ で, Az. N290 E である。しかし, かなりの観测点（新潟, 相川, 高田, 松本, 名古屋, 潮岬, 等) が, この 4 象限型の区分飞, 合致していな w。

このように，4象限型に区分しようとする㚵力が払われたが，期待した結果は得られなかった。というこ

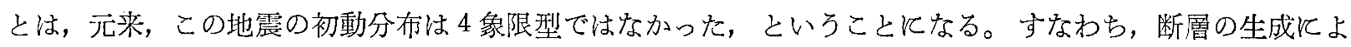

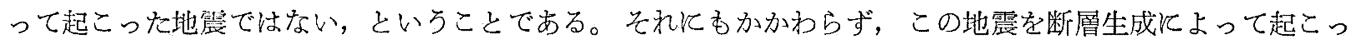
た地震であると想定して，地震予知 Project 飞役立てようとしている。こんなことで, 地震予知が可能々な るであるうか。

Fig. 5 は, 箻者（1965 年）が，岩しょう懪発説の立場から，区分したものである。この地震の深さは 40 km であったから, 勿論, Fig. 6 飞示すような Mohorovicic 層の存在を用いている。当時は, まだ, 外国 の観測資料が揄っていなかったので，日本だけの凟料から，節円錐の Element を算出した。それねよると， 
非刘称押円錐型（A型）の主軸が $145^{\circ}$ 傾むいていて，その Az. は N95 E であった。最近となって I.S.C の資料が入手できても, Fig. 5 の左上の図の上うに，何等補正を加光る必要がなかったものである。しかも， 日本の全資料は，一つの例外もなく，うまく，この型炕まっている。

Fig. 7 は，昭和 38 年 3 月 27 日 (1963年) の越前岬沖地震の初動分布を, 市川政治（1971年）が断層説の

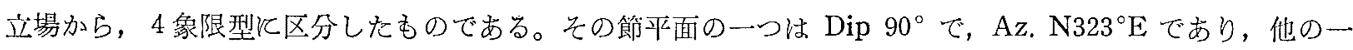
つは Dip $90^{\circ}$ で, $\mathrm{Az} . \mathrm{N} 233^{\circ} \mathrm{E}$ となっている。これも多くの観測点（石巻, 仙台, 福島, 前橋, 長野, 松 代, 神戸，姫路，高山，高知，奄美大島，等）が，この 4 象限型の区分飞，はまっていない。

Fig. 8 は，同じ越前岬沖地震の初動分布を，阿部勝征 (1973年地震学会飞て発表) が，4象限型飞区分し たあのである。これは Mohorovicic 層を認めているので，前記市川の区分よりは，上くなっている。それで も, 前橋, 福井, 鶴賀, 舞鶴, 神戸, 等は, この区分飞合致していない。しかも, これらの観測点は全部, 転向円内飞ある。結局, 転向円外の観測資料を，4像限型飞区分し上うとすると，転向円内の観測資料が，

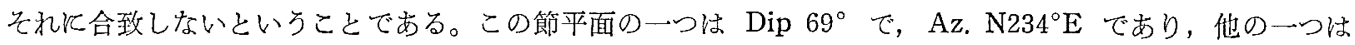
Dip $68^{\circ}$ で, Az. N144E である。

このようК，かなり苦学して，4象限型欧しょうとしているのであるが，4象限型ねはならないのであ る。

Fig. 9 は, 前 2 者と同じ地震の初動分布を, 岩しょろ懪発説の立場から，筆者が区分したものである。地 震の梁さは $40 \mathrm{~km}$ が妥当であるので, Fig. 6 亿示した Mohorovicic 層の存在を考虑に入れてある。これ も，非対称押円錐型（A型）の主軸が $100^{\circ}$ 傾いていて，炎の Az.は $\mathrm{N} 2{ }^{\circ} \mathrm{E}$ となっている。これは，転向円 外の資料も転向円内の資料も，矛盾なく，うまく区分している。

これらのことから，元来，初動分布は，4象限型ではなく， 円錐型と考学るべきであることが分る。そる

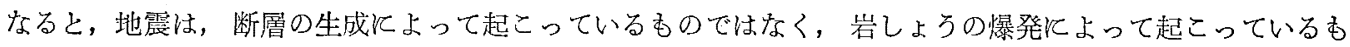
のであることが分る。

* 篗者はこの論文提出中の 1974 年 8 月 3 日病気のため急逝したのでこれが遺稿となった。 